Maria Magdalena Zagoto ${ }^{1}$, Nevi Yarni ${ }^{2}$, Oskah Dakhi ${ }^{3}$

\section{PERBEDAAN INDIVIDU DARI GAYA BELAJARNYA SERTA IMPLIKASINYA DALAM PEMBELAJARAN}

\begin{abstract}
Abstrak
Setiap manusia diciptakan oleh Sang Khalik dengan segala keunikan dan karakteristik atau ciri khasnya masiing-masing. Hal ini dinamakan sebagai perbedaan individu (individual differences). Perbedaan individu adalah perbedaan kemampuan dan karakteristik (kognitif, kepribadian, keterampilan fisik, dan lain sebagainya) antar peserta didik pada jenjang usia tertentu dan dalam setiap kelompok tertentu. Melalui praktik dan aktivitas pendidikan, kita dapat mengakomodasi perbedaan individual para siswa. Demikian pula halnya gaya belajar antar satu sama lain juga berbeda. Ada yang gaya belajar visual, auditori, dan kinestetik. Pentingnya untuk mengenali gaya belajar anak didik sehingga guru bisa memvariasikan gaya mengajar, metode pembelajaran yang cocok diterapkan dalam proses pembelajaran. Metode analisis yang dilakukan adalah studi pustaka, dengan cara mencari beberapa sumber yang telah diterbitkan oleh penulis/peneliti lain terkait dengan perbedaan individu dari gaya belajarnya. Sebagai pengajar kita harus mampu memilih berbagai cara/teknik yang dapat mengakomodasi perbedaan-perbedaan siswa secara personal dan mengoptimalkan kemajuan maupun kemampuan interpersonal masing-masing peserta didik dalam jangka panjang terutama jika ditinjau dari gaya belajarnya sehingga proses pembelajaran terlaksana secara optimal.
\end{abstract}

Kata Kunci: Perbedaan Individu, Gaya Belajar, Pembelajaran.

\begin{abstract}
Every human being was created by the Creator with all its unique characteristics and characteristics. This is called individual differences. Individual differences are differences in abilities and characteristics (cognitive, personality, physical skills, etc.) among students at a certain age and each particular group. Through educational practices and activities, we can accommodate individual student differences. Likewise, learning styles between students are different. There are visual, auditory, and kinesthetic learning styles. It is important to know the learning styles of students so that the teacher can adjust or vary the teaching style, appropriate learning methods applied in the learning process. The analytical method used is a literature study, by reviewing or reviewing various literature that has been published by academics or other researchers related to individual differences from their learning styles. As teachers, we must be able to identify various ways that can be taken to accommodate individual student differences and maximize the development or interpersonal success of each of them in the long run, especially if viewed from the learning style so that the learning process is implemented optimally.
\end{abstract}

Keywords: Individual Differences, Learning Styles, Learning.

\footnotetext{
${ }^{1}$ Mahasiswa Prodi Ilmu Pendidikan, Universitas Negeri Padang Alamat email Marya2949@gmail.com

${ }^{2}$ Dosen/Staf pengajar Prodi Ilmu Pendidikan, Universitas Negeri Padang

${ }^{3}$ Mahasiswa Prodi Pendidikan Teknologi Kejuruan, Universitas Negeri Padang
} 


\section{PENDAHULUAN}

Pada hakikatnya setiap individu diciptakan dengan segala keunikannya dan dengan karakteristik masing-masing. Faktor keturunan/hereditas atau bawaan lahir serta faktor lingkungan merupakan faktor yang berpengaruh terhadap perbedaan personal/individu. Kedua faktor ini berpengaruh terhadap perkembangan dan pertumbuhan peserta didik. Kemungkin dari faktor tersebut ada yang lebih berpengaruh, tetapi keduanya tetap berpengaruh, serta antar individu tidak ada yang sama meskipun itu merupakan manusia yang dilahirkan kembar (Zagoto, 2018; Sarumaha, 2018).

Adapun macam-macam gaya belajar akan diulas yaitu (1) Gaya belajar secara visual yaitu kemampuan belajar dengan melihat. (2) Gaya belajar auditory yaitu mempunyai kemampuan yang lebih baik dalam pendengaran. (3) Gaya belajar kinestetik, belajar dengan melibatkan gaya gerak. Guru sebaiknya tidak menyamakan semua anak didiknya. Untuk mendapatkan pembelajaran yang optimal, seorang guru harus mengetahui apa saja yang dibutuhkan siswanya dan berusaha membantu memenuhi kebutuhan belajarnya (Zagoto., M. M, \& Dakhi, O., 2018).

\section{METODOLOGI PENELITIAN}

Metode penelitian yang digunakan dalam pengumpulan informasi adalah dengan menggunakan studi pustaka.Metode studi pustaka atau studi literature adalah mengumpulkan informasi dari buku-buku dan referensi lainnya yang terkait dengan masalah dan tujuan riset. Buku-buku dan literatur lain adalah sebagai sumber data yang akan diolah dan dianalisis oleh peneliti. Penelitian dilakukan dengan mengumpulkan sumber kepustakaan untuk mendapatkan informasi/keterangan yang bersifat teoritis.

\section{HASIL DAN PEMBAHASAN}

\section{Pengertian Gaya Belajar}

Gaya belajar ( Learning style) adalah suatu teknik yang lebih kita senangi dalam melakukan aktivitas berpikir, memproses serta mengerti/memahami suatu informasi (Gunawan, 2006:139). Lebih lanjut DePorter \& Hernacki (2013) mendefenisikan gaya belajar sebagai perpaduan dari cara seseorang menyerap, mengatur, dan mengolah suatu informasi. Sedangkan menurut Menurut Nasution (2009:94) dalam bukunya Berbagai Pendidikan dalam Proses Belajar Mengajar, gaya belajar didefenisikan sebagai cara yang konsisten yang dilakukan oleh seorang anak didik dalam merespon stimulus/informasi, teknik mengingat, berfikir maupun dalam memecahkan soal. Hal ini berarti gaya belajar anak berhubungan dengan cara anak belajar dan tata belajar yang dominan disukainya. Gaya belajar diartikan sebagai tata belajar yang unik/khas bagi anak didik (Winkel, 2005:164; Dakhi, O., 2013).

Berdasarkan beberapa pengertian di atas, dapat disimpulkan bahwa gaya belajar dapat didefenisikan sebagai cara seseorang dalam merespon suatu informasi/pelajaran, menata, dan mengola informasi tersebut untuk solusi masalah dan mengaplikasikannya dalam kehidupannya. Gaya belajar adalah teknik/cara yang dimiliki seseorang untuk mengeksplor kemampuannya (Dakhi, O., 2013).

\section{Jenis-Jenis Gaya Belajar}

Menurut De porter \& Hernacki (2013) gaya belajar dikategorikan menjadi tiga, yaitu gaya belajar visual, auditori, dan kinestetik. 


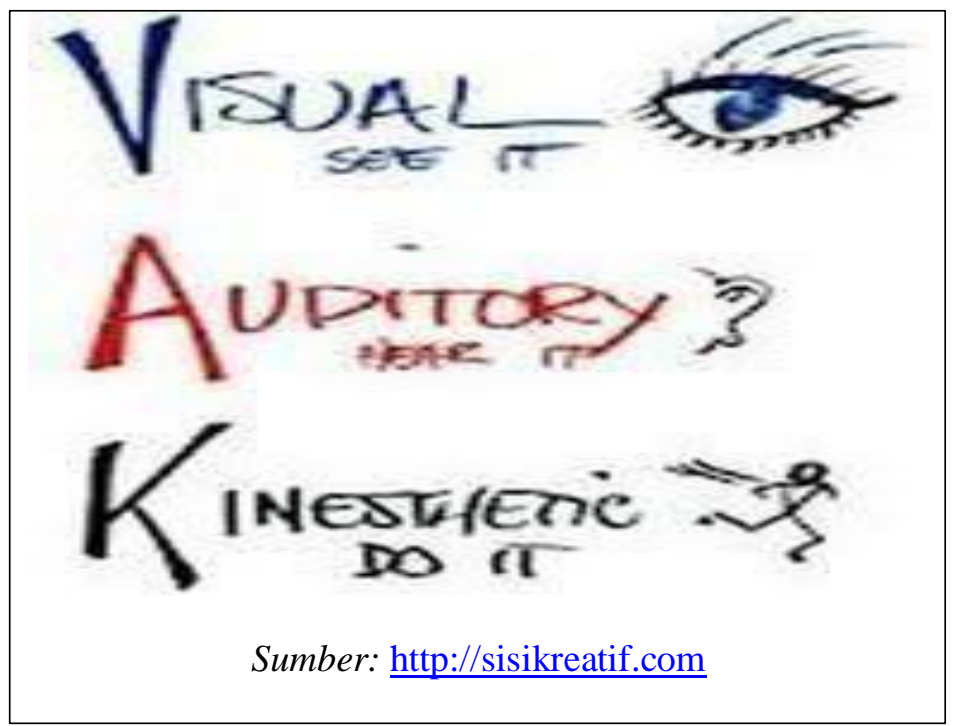

\section{a. Gaya Belajar Visual}

Gaya belajar visual (visual learners) lebih memfokuskan pada penglihatan. Gaya belajar visual mengakses pandangan visual, yang dihasilkan maupun diingat. Dalam gaya belajar tipe ini, potret, warna, maupun hubungan ruang, serta gambar/sketsa lebih menonjol. Anak didik dengan tipe visual memiliki kekhasan yakni: rapi dan terarah; bertutur kata dengan sesuai; perancang dan pengelola yang mantap; jeli, teliti,dan rinci; pelafal yang apik dan dapat melihat kata-kata yang sebenarnya dalam pikiran mereka; mengingat apa yang dilihat daripada yang didengarkan; pembaca yang tekun; sering menanggapi pertanyaan dengan jawaban yang pendek, ya atau tidak; lebih suka membaca daripada dibacakan; lebih suka melakukan presentasi/pertunjukkan daripada sekedar berceramah; dan lebih menyukai seni.

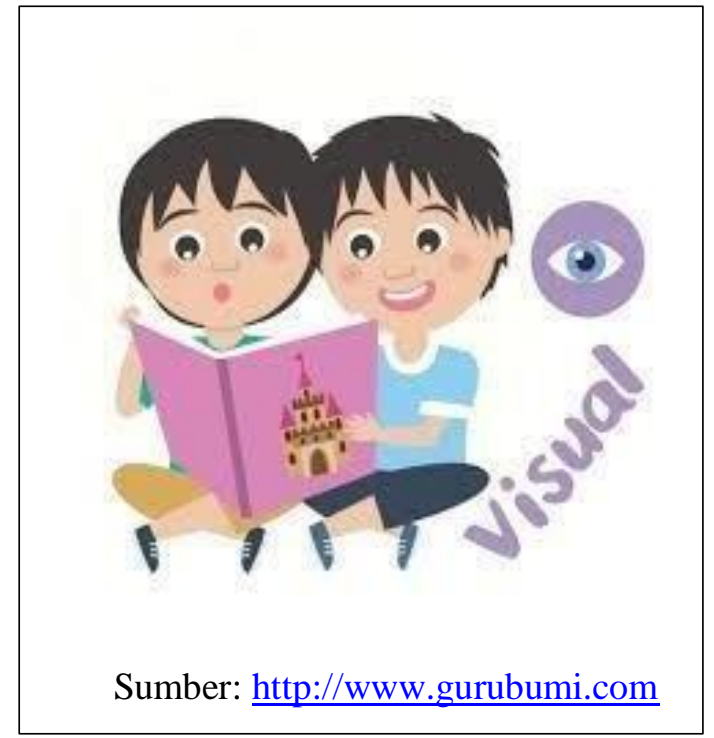

Anak dengan tipe visual harus memperhatikan mimik guru saat mengajar agar memahami bahan pelajaran. Mereka sangat tertarik duduk di bagian depan supaya bisa menyaksikan dengan jelas. Berpikir dengan mengaplikasikan potret/figura di otak mereka dan memahami sesuatu lebih cepat melalui animasi visual, seperti buku bergambar, maupun video. Anak dengan tipe visual lebih senang menulis secara lengkap untuk keterangan. 
Pendekatan untuk membantu proses belajar peserta didik dengan gaya belajar visual:

1. Manfaatkan materi/objek visual misalnya, peta dan gambar/diagram.

2. Manfaatkan warna untuk memudahkan memahami hal/poin penting.

3. Menganjurkan anak agar membaca buku-buku bergambar atau dengan animasi-animasi.

4. Memanfaatkan media-media digital separti: komputer/video.

5. Mengajak anak untuk mempresentasikan gagasannya ke dalam sketsa (gambar/diagram).

\section{b. Gaya Belajar Auditori}

Gaya belajar auditori (auditoryal learners) memfokuskan pada indera pendengaran dalam mengingat sesuatu. Ciri khas gaya belajar tipe ini benar-benar menggunakan indera pendengaran sebagai alat esensial untuk menyerap informasi/pengetahuan. Artinya, anak didik harus mendengar, baru selanjutnya dapat memahami/mengingat informasi yang diperoleh tersebut. Gaya belajar ini mengelola segala jenis suara dan kata. Nada, musik, irama,dan dialog internal serta suara lebih ditonjolkan untuk gaya belajar tipe ini.

Seseorang dengan tipe auditorial memiliki ciri-ciri yakni: mudah terganggu oleh keributan; mengucapkan tulisan atau membaca dengan besuara sambil menggerakkan bibir mereka saat sedang membaca; membaca dengan suara lantang dan dapat mengulangi kembali serta mencontohkan warna suara, birama, dan nada; merasa kesulitan dalam menulis tetapi memiliki kompetensi dalam menyampaikan/mempresentasikan cerita; pembicara yang pandai/fasih; menyukai musik, suka memberi pendapat, dan mendeskripsikan suatu hal dengan detail; merasa kesulitan dengan hal-hal yang berkaitan dengan visualisasi, misalnya mengelompokkan suatu unsur-unsur agar sesuai satu dengan yang lain;

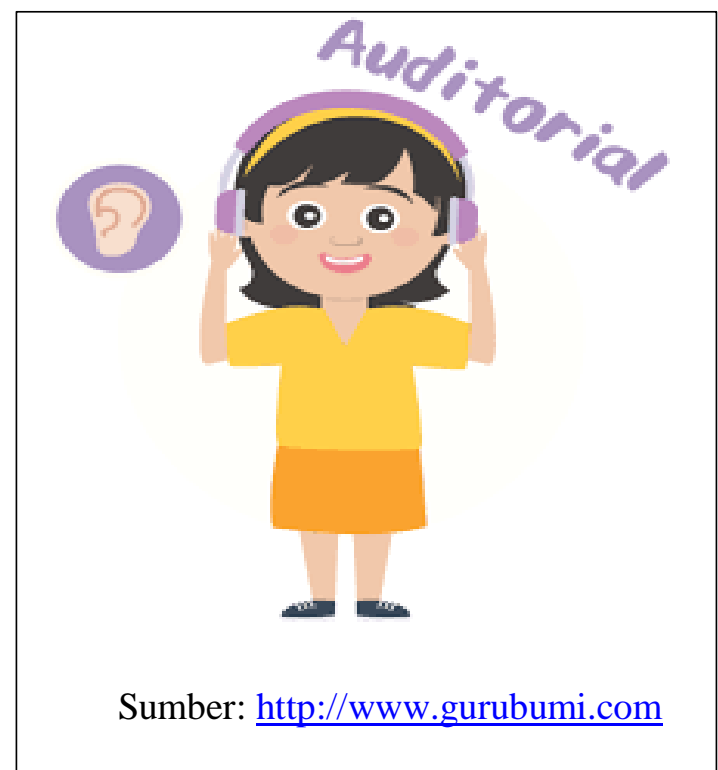

Pendekatan/strategi untuk membantu proses belajar anak auditori :

1). Selalu libatkan anak dalam kegiatan diskusi

2). Beri motivasi untuk membaca bahan pelajaran dengan bersuara

3). Variasikan penggunaan musik saat membelajarkan anak

4). Diskusikan ide secara lisan

5). Ajak anak untuk merekam bahan pelajarannya ke dalam kaset dan mendengarkannya sebelum tidur. 


\section{c. Gaya Belajar Kinestetik}

Gaya belajar kinestetik (kinesthetic learners) mensyaratkan personal untuk menyentuh/menjamah sesuatu yang menyampaikan informasi/data tertentu untuk diingat peserta didik. Anak kinestetik belajar melalui bergerak, melakukan, ataupun menyentuh. Anak dengan tipe ini susah duduk tenang/diam karena hasrat mereka untuk bereksplorasi dan beraktivitas begitu kuat. Anak dengan gaya belajar ini belajar melalui gerak dan sentuhan.Ciri-ciri anak kinestetik yaitu: menyentuh/memegang/meraba untuk memperoleh perhatian orang, berbicara dengan pelan, merespon perhatian fisik, berdiri dekat dengan lawan bicara, selalu berorientasi pada fisik dan banyak bergerak; memiliki pertumbuhan/perkembangan awal otot-otot yang besar; belajar dengan memanipulasi dan praktik; menghafal/mengingat dengan cara berjalan/melihat; menunjuk bacaaan ketika sedang membaca; banyak menggunakan isyarat tubuh; dan tidak dapat duduk diam untuk waktu lama.

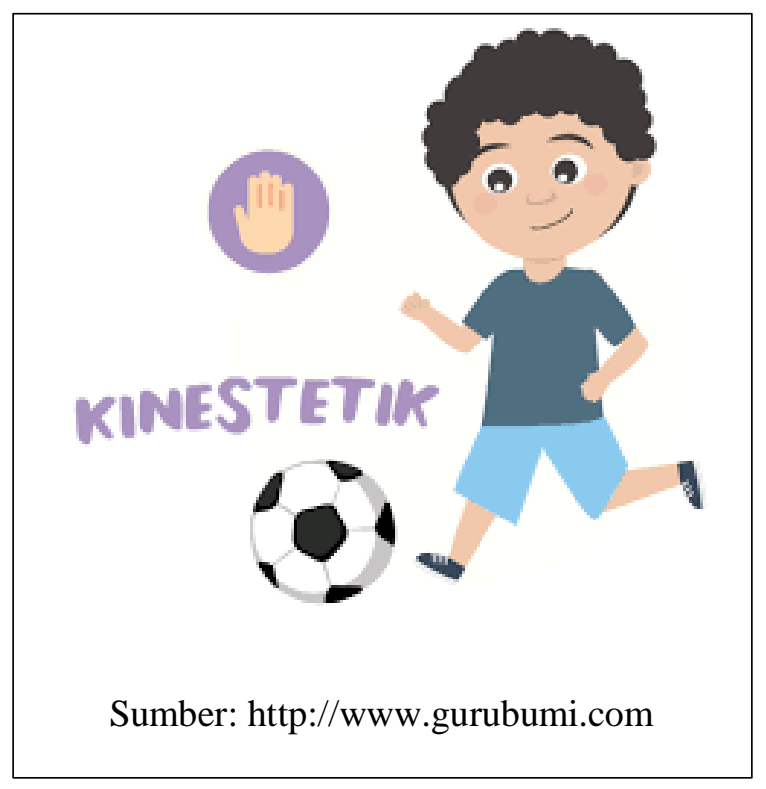

Strategi/pendekatan untuk membelajarkan anak kinestetik:

1. Tidak menharuskan anak untuk belajar hingga berjam-jam.

2. Ajak anak belajar dengan mengeksplorasi/menjelajahi lingkungannya (contohnya: belajar sambal menggunakan gunakan objek sesungguhnya dalam memahami konsep baru).

3. Tandai hal-hal penting suatu bacaan dengan warna terang.

4. Beri ijin anak untuk belajar sambil mendengarkan musik.

\section{Faktor-faktor yang Mempengaruhi Perbedaan Individu}

Menurut Rita Dunn dalam (Sugihartono, 2007) pelopor/perintis bidang gaya belajar yang lain telah mendapatkan banyak variabel yang berpengaruh terhadap gaya belajar siswa, yakni: sosiologis, fisik, emosi, serta lingkungan. Sebagian orang dapat belajar dengan baik dalam ruanagn dengan cahaya terang, sedangkan yang lainnya jika pencahayaan suram. 
Adapun faktor-faktor yang mempengaruhi perbedaan individu, antara lain :

a. Faktor Keturunan (Heriditas)

Menurut para ahli Biologi bahwa terjadinya individu adalah akibat bertemunya sel jantan dan betina. Pada setiap spesies/jenis makhluk jumlah dan bentuk kromosomnya selalu sama dan bila spesiesnya berbeda, akan berbeda pula jumlah dan bentuk chromosomenya. Gen dari sel jantan saling berpasangan dengan gen dari gen betina dengan cara yang berbeda beda. Cara yang berbeda-beda inilah yang menyebabkan perbedaan sifat individu. Perbedaan sifat individu inilah yang menyebabkan terjadinya perbedaan individu berdasarkan faktor keturunan.

b. Faktor Lingkungan/Keluarga

Lingkungan dalam arti luas meliputi lingkungan statis dan dinamis. Keadaan tempat maupun alam lebih bersifat statis, sedangkan lingkungan sosial lebih bersifat dinamis. Lingkungan statis memberi pengaruh/dampak yang tentunya berbeda dengan individu di lingkungan tertentu. Demikian juga lingkungan dinamis/pengaruh lingkungan sosial juga berpengaruh terhadap orang-orang yang tinggal di lingkungan tersebut. Hal-hal semacam itu akan membuat perbedaan sifat/pembawaan satu sama lain.

c. Faktor Campuran

Dari uraian di atas ternyata bahwa baik keturunan/hereditass maupun faktor lingkungan berpengaruh terhadap perbedaan massing-masing individu.

\section{Implikasi Perbedaan Individual dalam Proses Pembelajaran}

Perbedaan individu sangat menarik perhatian para ilmuwan, termasuk De Petter dan Hearchi. Ia menjelaskan berbagai macam tipe orang dalam belajar. Setiap orang memiliki cara/metode belajarnya sendiri.

Siswa dengan tipe visual lebih banyak menyerap/menangkap informasi melalui indera penglihatan/mata, hal yang dapat dilakukan dalam memaksimalkan potensi belajarnya adalah:

a. Posisikan tempat duduk di bangku paling depan, agar mereka dapat langsung melihat yang dituliskan atau digambarkan/diterangkan guru di papan tulis.

b. Perbanyak diagram, peta konsep, flow-chart dalam menjelaskan bahan/materi.

c. Putarkan film. Ajak siswa untuk mencatat poin-poin penting.

d. Ilustrasi dan sketsa/gambar dalam pembelajaran

Siswa dengan tipe auditori lebih banyak menyerap/menangkaap informasi lewat indera pendengaran, hal yang bisa dilakukan dalam memaksimalkan potensi belajarnya adalah:

a. Maksimalkan penggunaan audio (musik, radio, dan sebagainya)

b. Saat belajar, biarkan mereka membaca dengan nyaring dan suara keras.

c. Sering buat/lemparkan pertanyaan-pertanyaan sederhana

d. Gunakan rekaman.

e. Bimbing mereka dalam menjelaskan dan mendeskripsikan dengan kata-kata.

f. Biarkan mereka mencatat hal yang mereka pahami tentang satu mata pelajaran.

g. Belajar dalam kelompok.

Siswa dengan tipe kinestetik, lebih banyak memperoleh/menyerap informasi melalui gerakan fisik, hal yang dapat dilakukan dalam memaksimalkan potensi belajarnya adalah: 
a. Belajar melalui praktek lapangan (field trip).

b. Melakukan pertunjukan

c. Membuat figuran/model/contoh-contoh.

d. Kegiatan praktikum di laboratorium.

e. Perbanyak simulasi serta role playing.

\section{SIMPULAN}

Perbedaan individu yaitu perbedaan kemampuan dan karakteristik (kognitif, kepribadian, keterampilan fisik, dan lain sebagainya) antar anak didik pada usia tertentu dan dalam setiap kelompok. Melalui praktik dan aktivitas pendidikan, kita dapat mengakomodasi perbedaan individual para siswa. Perbedaan individu umumnya merupakan hasil hubungan/interaksi dari pengaruh hereditas/keturunan dan pengaruh lingkungan secara berbarengan, yang akhirnya menciptakan/menghasilkan manusia yang khas/unik. Namun kondisi lingkungan termasuk kondisi dikelas juga memiliki pengaruh yang berarti terhadap kemampuan dan perilaku siswa.

Gaya belajar atau learning style merupakan cara seseorang dalam menyerap informasi/pelajaran, mengatur, dan mengola informasi tersebut untuk memecahkan masalah dan menerapkannya dalam kehidupan sehari-hari yang di didasarkan pada kepribadian peserta didik masing-masing. Gaya belajar secara garis besar dibedakan menjadi tiga jenis yaitu: gaya belajar visual, auditori dan kinestetik.

\section{DAFTAR PUSTAKA}

Arikunto, S. 2006. Metode Penelitian Kualitatif. Jakarta: Bumi Aksara

Dakhi, O. "Aplikasi Pendeteksian Kerusakan File Akibat Virus Dengan Menggunakan Metode Heuristic." Pelita Informatika Budi Darma, vol. 4, no. 1, pp. 35-41, 2013.

Dakhi, O. 2013. Belajar Javascript Dengan Mudah Dan Detail. Jakarta: Dapur Buku. pp. 1-202.

DePorter, Bobbi \& Mike Hernacki. 2003. Quantum Learning. Membiasakan Belajar Nyaman dan Menyenangkan. Bandung: Penerbit Kaifa

DePorter, Bobbi. 2013. Quantum Learning. Membiasakan Belajar Nyaman dan Menyenangkan. Bandung: Penerbit Kaifa

Gunawan, Adi W. 2006. Genius Learning Strategi. Jakarta: Pustaka Utama.

Nasution, S. 2009. Berbagai Pendekatan dalam Proses Belajar Mengajar. Bandung: Bumi Aksara

Sarumaha, R., Harefa, D., \& Zagoto, Maria M. (2018). Upaya Meningkatkan Kemampuan Pemahaman Konsep Geometri Transformasi Refleksi Siswa Kelas XII-IPA-B SMA Kampus Telukdalam Melalui Model Pembelajaran Discovery Learning Berbantuan Media Kertas Milimeter. Jurnal Education and development, Vol.6 No.1, 90-96. https://doi.org/10.37081/ed.v6i1.668

Sugihartono., Fathiyah, K. N, Harahap, F., Setiawati, F. A., \& Nurhayati, S. R. 2007. Psikologi Pendidikan. Yogyakarta: UNY Press.

Santrock, John W. 2008. Psikologi Pendidikan. Alih bahasa Tri Wibowo B.S., Jakarta: Kencana.

Winkel.WS 2005. Bimbingan dan Konseling di Institusi Pendidikan. Yogyakarta: Media Abadi.

Zagoto, Maria M. \& Dakhi, O (2018). Pengembangan Perangkat Pembelajaran Matematika Peminatan Berbasis Pendekatan Saintifik Untuk Siswa Kelas XI Sekolah Menengah Atas. Jurnal Review Pendidikan dan Pengajaran, 1(1), 157-170.

Zagoto, Maria M. (2018). Pengembangan Perangkat Pembelajaran Matematika Berbasis Realistic Mathematic Educations Untuk Siswa Kelas V Sekolah Dasar, Jurnal Education And Development, vol. 3, no. 1, p. 53, Feb. 2018. https://doi.org/10.37081/ed.v3i1.139 